\title{
Developmental Expression of trkC, the Neurotrophin-3 Receptor, in the Mammalian Nervous System
}

\author{
Fabienne Lamballe, Richard J. Smeyne, and Mariano Barbacid \\ Department of Molecular Biology, Bristol-Myers Squibb Pharmaceutical Research Institute, Princeton, New Jersey 08543
}

The mammalian trkC gene encodes a tyrosine protein kinase that serves as a functional receptor for neurotrophin-3 (NT3). Here, we report that $t r k C$ is widely expressed in the developing and adult nervous system. Using in situ hybridization, we first detect trkC transcripts in the telencephalon and spinal cord of embryonic day 9.5 mouse embryos. In later embryonic development, $t r k C$ is expressed in various structures of the CNS including the caudatoputamen, septal nuclei, cerebellum, and brainstem. In the PNS, trkC hybridization appears to correlate, both temporally and spatially, with the outgrowth of axons toward their peripheral targets. trkC transcripts were also identified in the autonomous enteric nervous system as well as in some non-neural tissues such as the wall of the aorta and the acini of the submaxillary and sublingual glands. In the adult mouse, trkC gene expression is heterogeneously distributed throughout the brain, with highest levels in limbic and diencephalic structures. These results indicate that the trkC gene is widely expressed in the three identified branches of the mammalian nervous system and appears to correlate with the expression of NT-3, its cognate ligand. The apparent colocalization of trkC transcripts with NT-3 raises the possibility this neurotrophin exerts its trophic effects by a paracrine and/or autocrine mechanism.

[Key words: tyrosine kinase, trk, trkB, NGF, brain-derived neurotrophic factor, growth factors]

The generation of neurons during embryonic development as well as their survival in the adult animal is thought to be dependent upon availability of diffusible neurotrophic factors. These neurotrophins, however, can only exert their programmed trophic roles in those cells that express their cognate signaling receptors. Therefore, a detailed knowledge of the spatial and temporal pattern of expression of these trophic factors and their receptors should help us to understand better the ontogeny of the vertebrate nervous system.

One of the most important groups of neurotrophic factors in the nervous system is the NGF family. To date, four members of this gene family have been identitied. They include NGF (Levi-Montalcini, 1987), brain-derived neurotrophic factor (BDNF) (Bardc et al., 1982; Leibrock et al., 1989), neurotrophin-3

\footnotetext{
Received Jan. 22, 1993; revised May 20, 1993; accepted June 15, 1993.

We thank A. Lewin and L. Long for excellent technical assistance and P. Levitt for his generous gift of NF-H antibodies.

Correspondence should be addressed to Mariano Barbacid, Ph.D., Department of Molecular Biology, Bristol-Myers Squibb Pharmaceutical Research Institute P.O. Box 4000, Princeton, NJ 08543.

Copyright (C) 1994 Society for Neuroscience $0270-6474 / 94 / 140014-15 \$ 05.00 / 0$
}

(NT-3) (Ernfors et al., 1990a; Hohn et al., 1990; Jones and Reichardt, 1990; Maisonpierre et al., 1990b; Rosenthal et al., 1990), and neurotrophin-4 (NT-4) (Berkemeier et al., 1991; Hallbook et al., 1991; Ip et al., 1992). These molecules show a remarkable similarity in amino acid sequences and overall structural features but have a distinct range of neurotrophic activities (reviewed in Barde, 1989; Hefti, 1992). In the PNS, NGF supports the growth and survival of sympathetic neurons as well as that of certain sensory neurons such as those present in the dorsal root ganglia (DRG) and the trigeminal ganglion. NGF, however, does not support neurons derived from the nodose ganglia. In the CNS, the neurotrophic activity of NGF is restricted to cholinergic neurons of the basal forebrain and the striatum. BDNF, like NGF, supports DRG neurons in the PNS and septal cholinergic neurons in the CNS. Moreover, BDNF has neurotrophic activity in CNS retinal ganglion cells, GABAergic neurons of the basal forebrain, and dopaminergic neurons of the substantia nigra, as well as in peripheral neurons derived from nodose ganglia (Lindsey and Rohrer, 1985; Johnson et al., 1986; Thanos et al., 1989; Alderson et al., 1990; Hyman et al., 1991; Knusel et al., 1991).

NT-3 mimics NGF in its ability to elicit fiber outgrowth in sympathetic ganglia and BDNF in its trophic activity on neurons from nodose ganglia. Unlike BDNF, NT-3 does not have neurotrophic activity on central cholinergic or dopaminergic ncurons (Johnson et al., 1986; Knusel et al., 1991). More recently, Collazo et al. (1992) have reported that NT-3 can enhance the proliferation of embryonic hippocampal precursors. The neurotrophic properties of NT-4, a neurotrophin primarily expressed outside of the brain, are beginning to be explored. NT-4 can promote neuritic outgrowth in dorsal root and nodose, but not in sympathetic ganglia (Hallbook et al., 1991). Since NT-4 mediates its trophic effects through the same signaling receptors as BDNF (Ip et al., 1992; Klein et al., 1992), it is likely that both neurotrophins will exhibit the same pattern of activity in in vitro assays. However, their in vivo activity will depend on their spatial and temporal pattern of expression as well as that of their cognate receptor(s).

The distribution of NGF, BDNF, and NT-3 transcripts reveals a general overlap in several regions of the CNS, although significant differences have been observed. For example, high levels of BDNF mRNA can be found in the CA2, CA3, and hilus region of the hippocampus, while NT-3 mRNA has been predominantly detected in the $\mathrm{CA} 1$ and $\mathrm{CA} 2$ regions (Ernfors et al., 1990b). Moreover, there are significant variations in the temporal pattern of expression for these neurotrophins. Whereas NT-3 is highly expressed in the developing brain and its expression decreases in the adult, BDNF transcripts are relatively lowly abundant in the embryo and undergo a steady increase 
during the late stages of development until they reach levels of expression comparable to those observed for NT-3 in the adult brain (Maisonpierre et al., 1990a).

The neurotrophins of the NGF family bind to two classes of receptors that can be distinguished according to their binding affinities and biological properties. The low-affinity receptor p $75^{\text {LNGFR }}$ binds all members of the NGF family of neurotrophins with similar nanomolar affinitics (Chao, 1992). However, accumulating evidence indicates that $\mathrm{p} 75^{\mathrm{LNGFR}}$ is not involved in mediating the trophic effects of these neurotrophins (Klein et al., 1991 a; Birren et al., 1992; Ibanez et al., 1992; Jing et al., 1992). Instead, they appear to mediate their respective trophic activities through the Trk family of tyrosine protein kinase receptors (reviewed in Meakin and Shooter, 1992; Barbacid, 1993). These recepturs include the product of the $t r k$ proto-oncogene, gp 140 ${ }^{\text {rk }}$ (Martin-Zanca et al., 1989) and two related tyrosine protein kinases, gpl45 $5^{r k \mathrm{~B}}$ and $\mathrm{gpl} 45^{\mathrm{rkC}}$, encoded by the $\operatorname{trkB}$ (Klein et al., 1989; Middlemas et al., 1991) and trkC (Lamballe et al., 1991) genes, respectively. The Trk family of receptors is also responsible for providing functional specificity to the NGF neurotrophin family. Whereas NGF binds specifically to gp $140^{\prime r k}$, the related $\mathrm{gp} 145^{r k \mathrm{~B}}$ tyrosine protein kinase serves as a receptor for both BDNF and NT-4.

The third member of this tyrosine protein kinase family, $\mathrm{gp} 145^{\mathrm{rk} \mathrm{c}}$, is a receptor for NT-3. When ectopically expressed in NIH3T3 cells, gp 145 ${ }^{\text {rk }} \mathrm{C}$ binds NT-3 with high affinity in the low picomolar range (Lamballe et al., 1991). More importantly, this interaction results in receptor activation, phosphorylation of downstream signaling elements such as phospholipase $\mathrm{C} \gamma$, induction of DNA synthesis, and ultimately in the malignant transformation of these cells (Lamballe et al., 1991, 1993). NT-3 also binds to gp $140^{r k k}$ and gp $145^{r k \mathrm{~B}}$ receptors and mediates similar responses in NIH3T3 cells, albeit with 10-100-fold less potency (Cordon-Cardo et al., 1991; Glass et al., 1991; Ip et al., 1993). It is unlikely, however, that $\mathrm{gp} 140^{\text {trk }}$ and $\mathrm{gp} 145^{\mathrm{rk} \mathrm{B}} \mathrm{me}-$ diate the in vivo activities of this neurotrophin. For instance, NT -3 can only mediate neuronal differentiation of PC12 cells when they express gp $145^{\prime \prime K C}$ (Ip et al., 1993; Lamballe et al., 1993). Moreover, NT-3 promotes the survival of $t r k C$-, but not of $t r k$ - or $t r k$ B-expressing DRG neurons (Ip et al., 1993).

The present studies were first undertaken to determine the temporal and spatial appearance of $t r k \mathrm{C}$ transcripts and second to describe the dynamic changes that are observed throughout development. Previous studies have indicated that expression of the $t r k$ and $t r k \mathrm{~B}$ genes is tightly regulated during embryogenesis (Klein et al., 1990b; Martin-Zanca et al., 1990). While trk sequences remain confined to sympathetic and sensory neurons of neural crest origin throughout development, those of trkB extend to multiple structures of the CNS and PNS. Our results with trkC indicate that this gene is also expressed in multiple structures in the developing CNS and PNS. Moreover, trkC appears to be the only member of the trk gene family to be expressed in the autonomous enteric nervous system (ENS). These observations should contribute to our understanding of the molecular mechanisms that regulate the development and maintenance of the mammalian nervous system.

\section{Materials and Methods}

In situ hybridization. trkC riboprobes were generated from $\mathrm{pFL} 25$, a pGEM-3Zf $(+$ )-derived plasmid (Promega) that contains a 570 base pair Accl DNA insert of a mouse trk $\mathrm{C}$ cDNA clone. These sequences encode a 190 amino acid region of the extracellular domain of the mouse gp $145^{\text {irkc }}$ receptor, which corresponds to residues $111-300$ of its porcine counterpart. These sequences do not exhibit significant homology to the related $t r k$ and $t r k \mathrm{~B}$ genes and therefore should be specific for the $t r k \mathrm{C}$ gene (Lamballe et al., 1991). To generate the antisense riboprobe, pFL25 was linearized with SacI and transcribed from the SP6 promoter. The sense riboprobe used as a negative control was obtained by linearizing pFL25 with SphI followed by transcription from the T7 promoter. Probes were synthesized as described (Lamballe et al., 1991) using either ${ }^{35} \mathrm{~S}$ UTP ( $>1000 \mathrm{Ci} / \mathrm{mmol}$; New England Nuclear), or ${ }^{33} \mathrm{P}-\mathrm{UTP}(3000 \mathrm{Ci} /$ mmol; New England Nuclear). Sections were obtained from either 4\% paraformaldehyde-fixed paraffin-embedded $\mathrm{C} 57 \mathrm{Bl} / 6$ mouse embyros (5- $\mu \mathrm{m}$-thick sagittal sections) or flash-frozen adult mouse brain $(7-\mu \mathrm{m}$ thick coronal sections). Paraffin-embedded sections were deparaffinized in xylene, rehydrated through a gradient of ethanol solutions, and fixed in $4 \%$ paraformaldehyde. Frozen sections were thaw-mounted onto glass slides treated with 3-aminopropyltriethoxysilane (Sigma), and then immersion-fixed in $4 \%$ paraformaldehyde. Tissues were treated with proteinase $\mathrm{K}(20 \mu \mathrm{g} / \mathrm{ml}$ for paraffin-embedded sections and $40 \mathrm{ng} / \mathrm{ml}$ for frozen sections), refixed with $4 \%$ paraformaldehyde, immersed in triethanolamine/acetic anhydride solution for $10 \mathrm{~min}$, and dehydrated. Sections were hybridized with $5 \times 10^{7} \mathrm{cpm} / \mathrm{ml}$ of the respective riboprobes (see above) under stringent conditions [ $50 \%$ formamide, $10 \%$ dextran sulfate, $1 \times$ Denhardt's solution, $0.5 \mathrm{mg} / \mathrm{ml}$ yeast tRNA, and $10 \mathrm{~mm}$ dithiotreitol (L $\left.\left.\mathrm{I}^{\prime \prime} \mathrm{I}\right)\right]$ for $16 \mathrm{hr}$ at $52^{\circ} \mathrm{C}$. Hybridized sections were washed in $5 \times$ saline-sodium citrate (SSC), $10 \mathrm{~mm}$ DTT at $52^{\circ} \mathrm{C}$ for $15 \mathrm{~min}$ and then at $65^{\circ} \mathrm{C}$ for $30 \mathrm{~min}$ in a solution containing $50 \%$ formamide, $2 \times$ SSC, $10 \mathrm{~mm}$ DTT. Sections were washed once at room temperature and twice at $37^{\circ} \mathrm{C}$ in a solution containing $10 \mathrm{~mm}$ Tris- $\mathrm{HCl}, \mathrm{pH} \mathrm{7.5,}$ $0.5 \mathrm{~m} \mathrm{NaCl}$, and $5 \mathrm{~mm}$ EDTA, for $10 \mathrm{~min}$ each. Sections were incubated for $30 \mathrm{~min}$ at $37^{\circ} \mathrm{C}$ in the same buffer containing $20 \mu \mathrm{g} / \mathrm{ml}$ RNase A and $2 \mu \mathrm{g} / \mathrm{ml} \mathrm{RNase} \mathrm{T} 1$ and washed in the same solution without RNases at $37^{\circ} \mathrm{C}$ for $15 \mathrm{~min}$. Sections were finally washed in $50 \%$ formamide, $2 \times \mathrm{SSC}, 10 \mathrm{~mm}$ DTT at $65^{\circ} \mathrm{C}$ for $20 \mathrm{~min}$, in $2 \times \mathrm{SSC}$ at room temperature for $15 \mathrm{~min}$, and in $0.1 \times \mathrm{SSC}$ for $15 \mathrm{~min}$ at room temperature. After dehydration, sections were dipped into NTB-2 nuclear track emulsion (Kodak) and exposed for 1-3 weeks at $4^{\circ} \mathrm{C}$, developed, dehydrated, and coverslipped. Adjacent sections used for histological purposes were stained with $0.2 \%$ toluidine blue or cresyl violet.

Immunohistochemistry. Five-micrometer-thick paraffin-embedded sections were deparaffinized in xylene and hydrated through a series of graded ethanols. Following blocking of the sections with serum to eliminate nonspecific binding, they were incubated overnight at $4^{\circ} \mathrm{C}$ with a $1: 50$ dilution of anti-NFH, a monoclonal antibody directed against the high molecular weight neurofilament protein (a gift from $P$. Levitt, CABM, VMDNJ, Piscataway, NJ). After several rinses with PBS, sections were incubated for $30 \mathrm{~min}$ at room temperature with a $1: 50 \mathrm{di}-$ lution of a biotinylated secondary antibody conjugated to HRP (Histostain-SP kit, Zymed Laboratories, Inc.). Sections were washed in PBS and reacted with a substrate-chromagen mixture from the Histostain$\mathrm{SP}$ kit at room temperature for $15 \mathrm{~min}$. Sections were rinsed with distilled water and counterstained using hematoxylin (Meyers). Following the counterstain, sections were coverslipped using a glycerol-polyvinyl mounting medium. In control experiments, the primary antibody was replaced by preimmune serum.

\section{Results}

trkC expression is first detected in E9.5 embryos

trkC gene expression during mouse development was visualized using ${ }^{35} \mathrm{~S}$ - or ${ }^{33} \mathrm{P}$-labeled $t r k \mathrm{C}$ riboprobes synthesized from $\mathrm{pFL} 25$, a plasmid containing mouse trkC cDNA sequences encoding part of the extracellular domain of gp $145^{n * c}$ (Lamballe et al., 1991). These cDNA sequences have been found to be present in each of the known trkC transcripts (Lamballe et al., 1993). Embryos were examined for $t r k C$ expression starting at embryonic day 7.5 (E7.5). No specific trkC labeling was detected until E9.5 (data not shown). At this time, approximately 25 somites can be identified and the embryo has a distinct head, body, and tail (Rugh, 1990). In the CNS, specific trkC hybridization was observed in regions of the developing telencephalon and spinal cord (Fig. $1 A, B$ ). Outside of the nervous system, no significant levels of $t r k \mathrm{C}$ transcripts were detected. In control experiments 

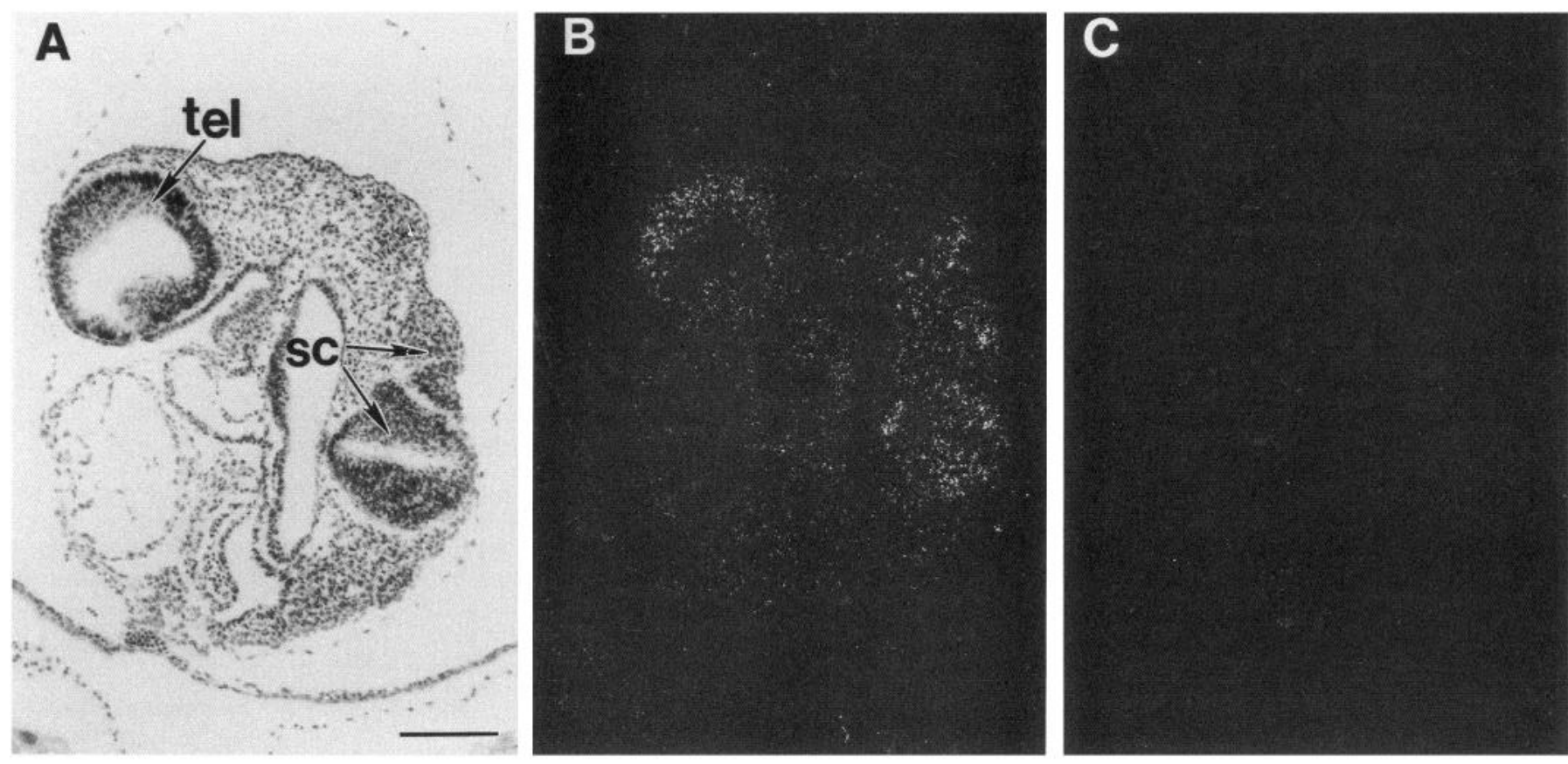

Figure 1. trkC expression in an E9.5 mouse embryo. $A-C$, Bright-field $(A)$ and dark-field $(B, C)$ views of a section of a twisted E9.5 mouse embryo demonstrating a sagittal section rostrally and coronal section caudally. The section was hybridized with antisense $(B)$ and sense $(C)$ trkC cRNA probes. Spinal cord $(s c)$ and telencephalon $(t e l)$ are labeled. Scale bar, $180 \mu \mathrm{m}$.

using a sense riboprobe, we did not detect specific hybridization in adjacent sections (Fig. 1C).

At E11.5, the CNS has fully differentiated into five well-described zones, including, from rostral to caudal, the telencephalon, diencephalon, mes- and metencephalon, and the myelencephalon. In addition, many interrelated organ systems outside of the CNS such as the circulatory and urogenital systems are beginning to form (Vogels et al., 1990; Perkins et al., 1991). Within the CNS, the highest levels of trkC expression were seen in the developing telencephalon, tectum (Fig. $2 A, B$ ), and optic stalk and recess (Fig. 2D,E). Similar levels of $t r k C$ expression were also found in the cervical, thoracic, and lumbar regions of the spinal cord (Fig. 2A,B). Lower levels of trkC hybridization were observed in the ventricular ridges that give rise to the caudatoputamen complex (Fig. $2 D, E$ ), the diencephalon, and its associated ganglionic eminence as well as in the mes- and metencephalic ventricular zone, which ultimately gives rise to neurons in the midbrain and cerebellum (Fig. $2 A, B, D, E$ ). No expression of the trkC gene was seen in the tufts of choroid plexus situated in the fourth ventricle (data not shown), a region rich in related $t r k B$ transcripts (Klein et al., 1990a). In the PNS, the spinal nerves express relatively low levels of trkC transcripts (Fig. $2 A, B$ ). In contrast, the DRGs depict high levels of trkC expression (Fig. 2D, E, G,H). Outside of the nervous system, trkC expression was observed in the pericardium surrounding the heart and in the walls of the aorta (Fig. 2A,B). Hybridization signal was also detected in the developing diaphragm and meso- nephric regions (Fig. 2A,B). In control experiments, no significant hybridization could be observed when adjacent sections were hybridized with the corresponding sense cRNA probe (Fig. $2 C, F)$.

\section{trk $C$ is widely expressed in midgestation embryos}

At E13.5, many of the CNS structures seen in the adult begin to differentiate, including, but not limited to, the septal nuclei, specific thalamic nuclei, the cerebellum, the pituitary via Rathke's pouch, and several cranial ganglia. In the CNS, trkC expression is observed at relatively high levels in the telencephalon, septal nuclei, and spinal cord, and at lower levels in the developing hypothalamus, mesencephalon, and brainstem (Fig. $3 A, B$ ). In each of these structures, the labeling is relatively homogeneous, with no distinct subnuclei expressing substantially higher levels of $t r k \mathrm{C}$ mRNA than its neighbor. Two exceptions were observed. In the tectum, high levels of $t r k \mathrm{C}$ expression are seen throughout its superficial layers, while the more inferior layers contain little $t r k \mathrm{C}$ mRNA (Fig. $3 D, E$ ). Second, the ventricular neuroepithelium that gives rise to the Purkinje and Golgi cells of the cerebellum demonstrates high levels of $t r k C$ expression in its ventral zone, with little hybridization signal noted in the more dorsal cerebellum (data not shown). Interestingly, the diencephalic ganglionic eminence, which expressed high levels of trkC in E11.5 embryos, does not exhibit detectable signal at E13.5 (Fig. 3B). In the PNS, we observed high levels of trkC expression in two cranial ganglia, including the trigeminal gan-

Figure 2. trkC expression in an E11.5 mouse embryo. $A-C$, Bright-field $(A)$ and dark-field $(B, C)$ photomicrographs of a midsagittal section through an E11.5 mouse embryo. $D-F$, bright-field $(D)$ and dark-field $(E, F)$ photomicrographs of a sagittal section lateral to that shown in $A$. Sections were hybridized with antisense $(B, E)$ or sense $(C, F)$ trkC cRNA probes. $G$ and $H$, Enlarged views of developing DRGs shown in $D$ and $E$, respectively. Labeled are aorta $(a)$, anlage of the caudatoputamen complex $\left(c p_{a}\right)$, diaphragm (dia), dorsal root ganglia (drg), ganglionic eminence of the diencephalon ( $g e$ ), mesonephric region (mes), mes- and metencephalic ventricular zone ( $m v z)$, optic recess and stalk (os), pericardium ( $p c$ ), spinal cord (sc), spinal nerves (sn), tectum (tec), and telencephalon (tel). Scale bars: $A-F, 1200 \mu \mathrm{m} ; G$ and $H, 160 \mu \mathrm{m}$. 

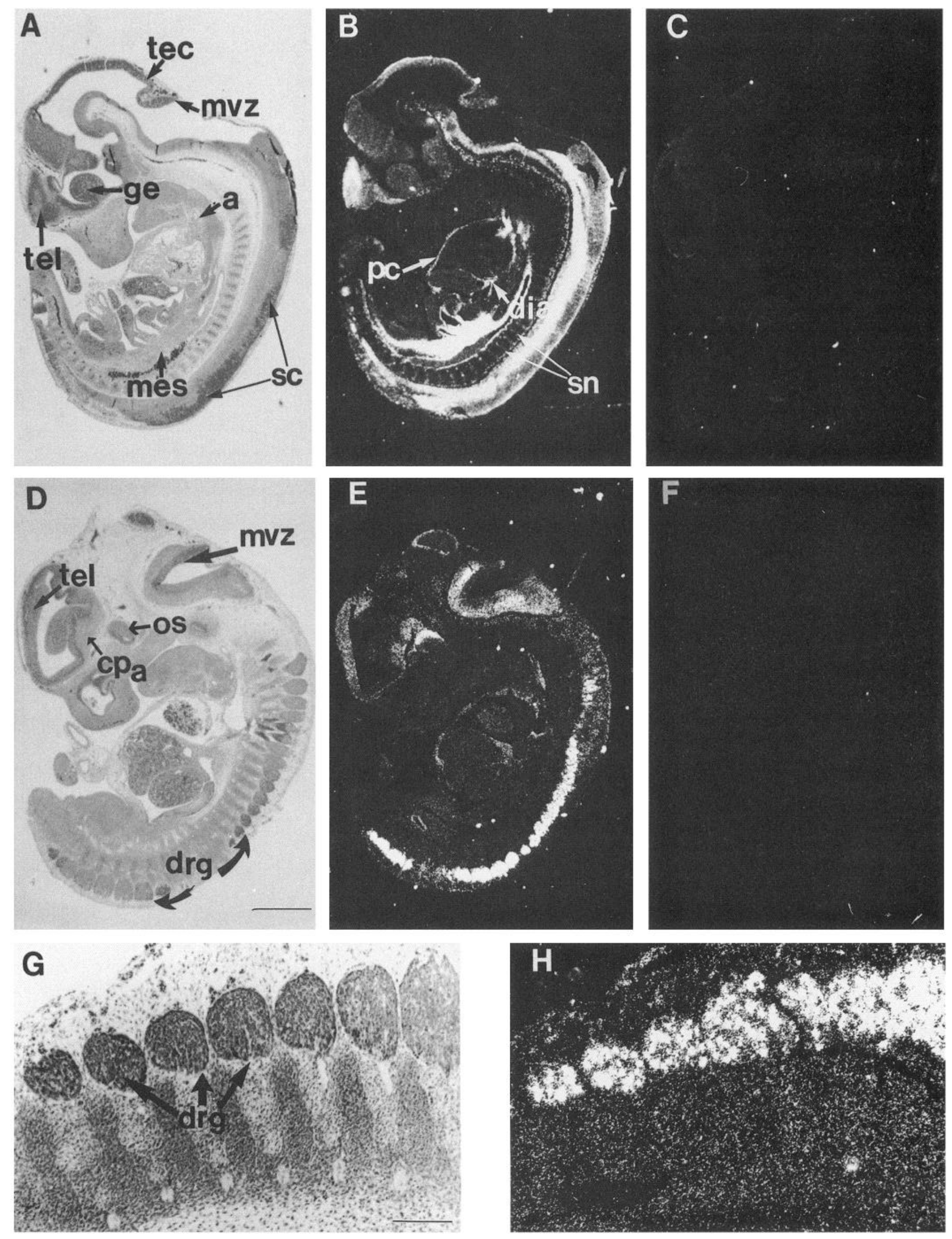

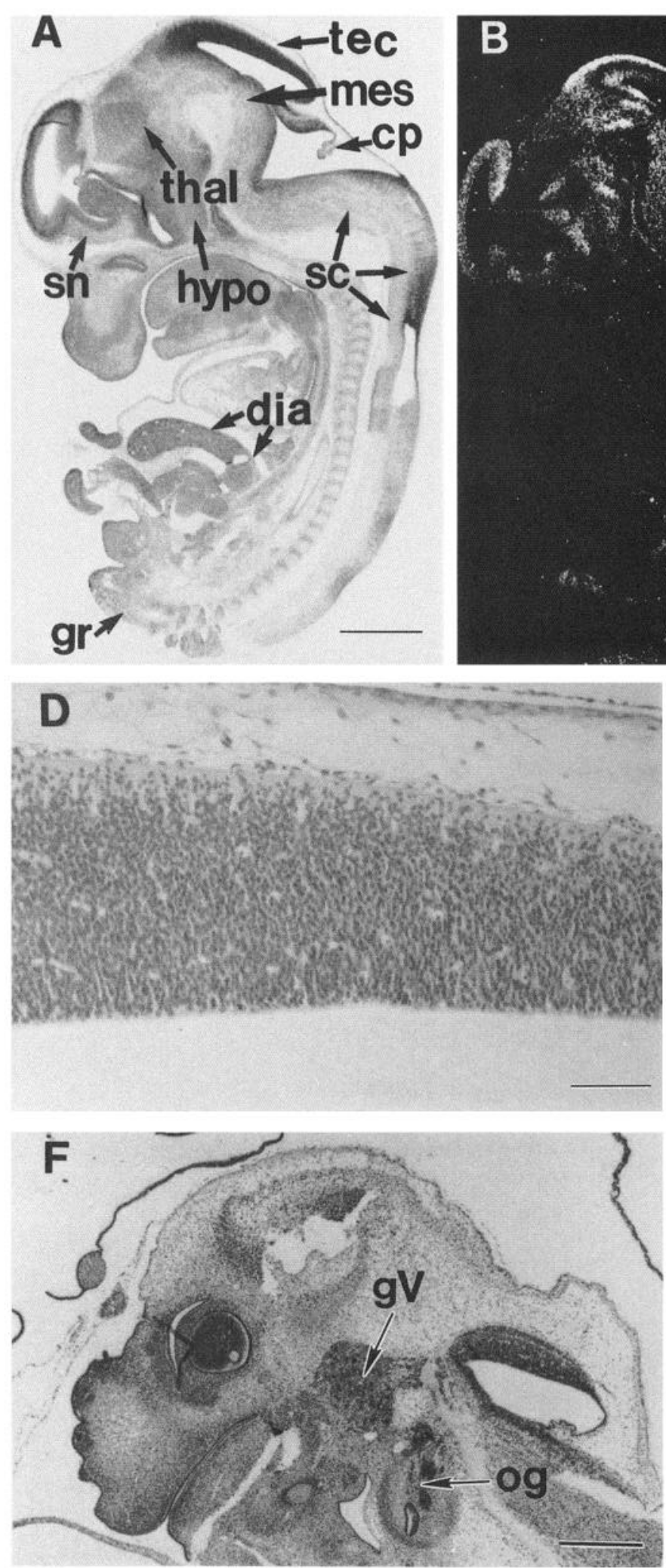
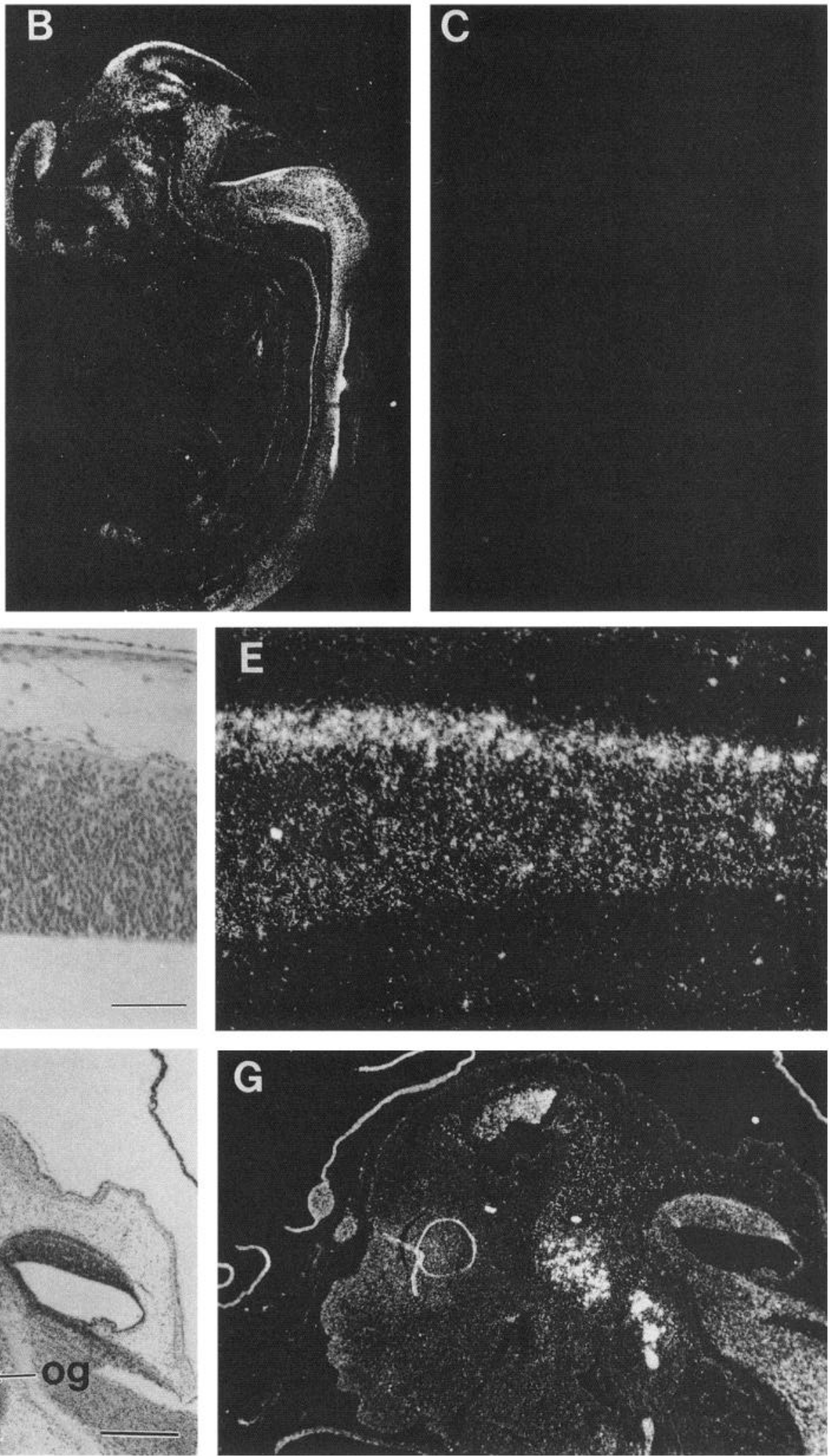

Figure 3. trkC expression in an E13.5 mouse embryo. $A-C$, Bright-field $(A)$ and dark-field $(B, C)$ photomicrographs of a midsagittal section through an E13.5 mouse embryo. $D$ and $E$, Enlarged view of tectum depicted in $A$ and $B$, respectively. Note the heterogeneity of the labeling in the different subregions of this structure. $F$ and $G$, Bright-field $(F)$ and dark-field $(G)$ photomicrographs of sagittal sections through the trigeminal and otic ganglia. Sections were hybridized with antisense $(B, E, G)$ or sense $(C)$ trkC cRNA probes. Labeled are choroid plexus $(c p)$, diaphragm (dia), genital ridge $(g r)$, hypothalamus (hypo), mesencephalon (mes), otic ganglion $(o g)$, septal nuclei $(s n)$, spinal cord (sc), tectum $(t e c)$, thalamus (thal), and trigeminal ganglion $(\mathrm{gV})$. Scale bars: $A-C, 1000 \mu \mathrm{m} ; D$ and $E, 60 \mu \mathrm{m} ; F$ and $G, 50 \mu \mathrm{m}$. 

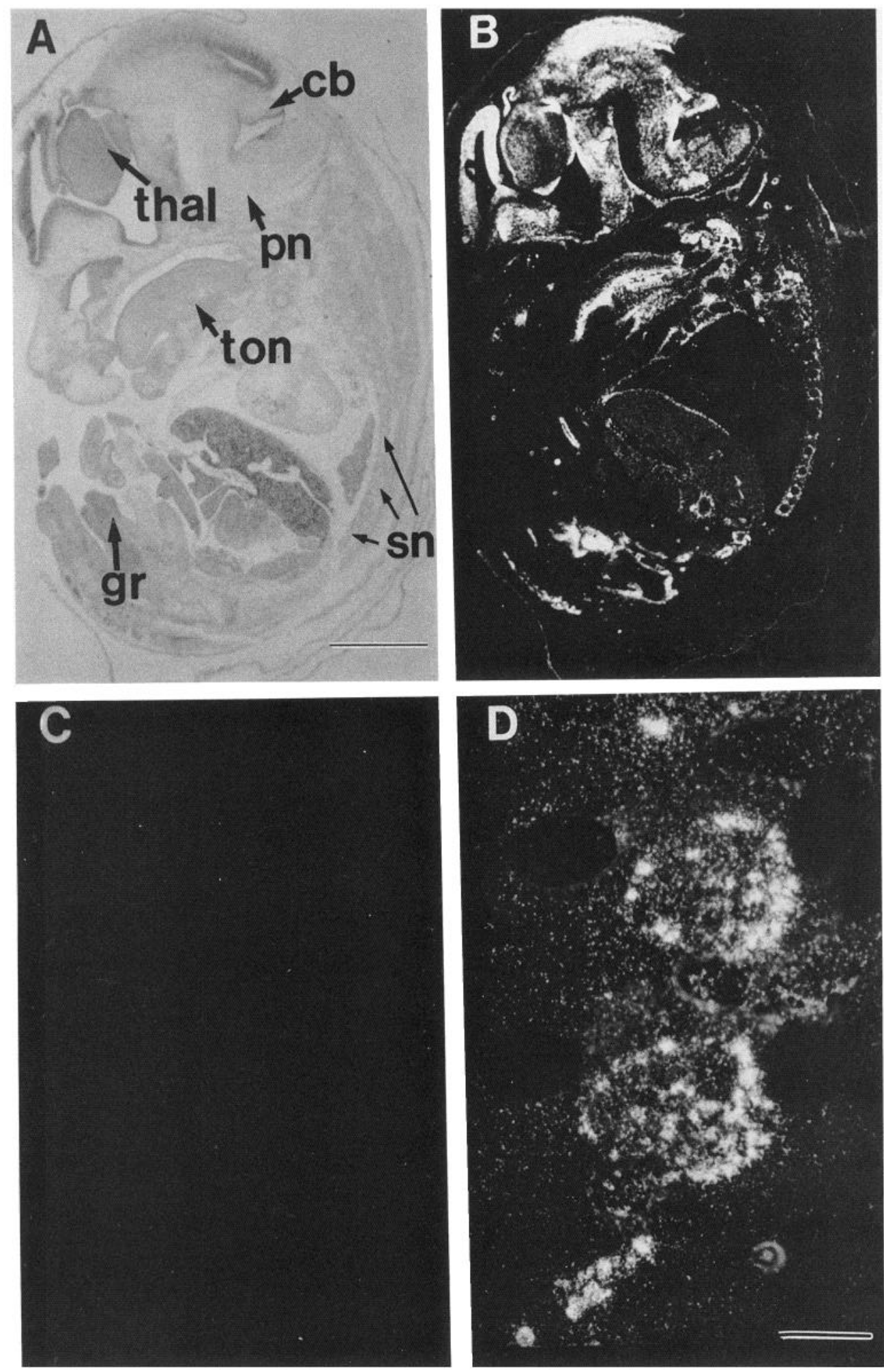

Figure 4. trkC expression in an E15.5 mouse embryo. $A-C$, Bright-field $(A)$ and dark-field $(B, C)$ photomicrographs of a midsagittal section through an E15.5 mouse embryo. Adjacent sections were hybridized with antisense $(B)$ and sense (C) $t r k \mathrm{C}$ cRNA probes. $D$, Dark-field micrograph of DRGs hybridized with trkC antisense riboprobe. These DRGs were photographed in a section sagittal to the one depicted in $A-C$. The majority of the trkC transcripts are localized at the periphery of the ganglia. Labeled are cerebellum $(c b)$, genital ridge $(g r)$, pontine nuclei $(p n)$, spinal nerves $(s n)$, thalamus (thal), and tongue (ton). Scale bars: $A-C, 1350 \mu \mathrm{m} ; D, 200 \mu \mathrm{m}$. glion, which gives rise to projections throughout the facial region, and the otic ganglion, which provides innervation to the auditory system (Fig. $3 F, G$ ). Outside the nervous system, expression of $t r k \mathrm{C}$ was limited to regions around the heart, including the aorta and pericardium, as well as the diaphragm and gut (Fig. $3 A, B$ ). As in previous embryonic stages, specificity of trkC expression in the above sections was demonstrated through the use of a sense cRNA probe (Fig. $3 C$ ).
At the E15.5 stage, there is further differentiation of the CNS, specifically in the regions of the cerebellum and hippocampus. trkC hybridization signal is diffusely distributed through most levels of the central neuraxis (Fig. $4 A, B$ ). Highest levels are observed in the tectum, telencephalon, septal region, mesencephalon, brainstem, and the germinal trigone of the developing cerebellum (Fig. $4 A, B$ ). In addition, trkC hybridization was newly noted in the pontine nuclei and in the developing hippocam- 

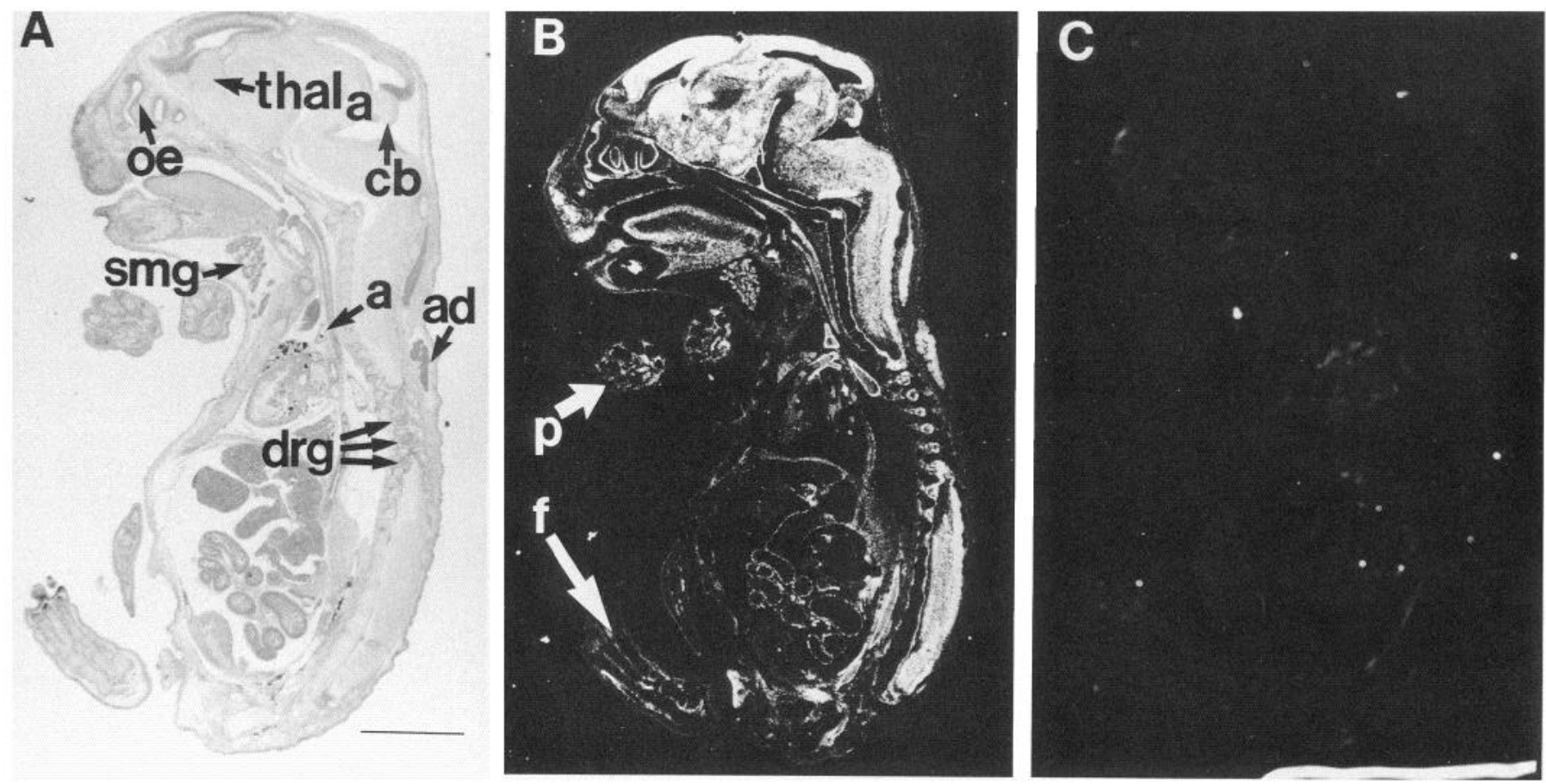

Figure 5. trkC expression in an E17.5 mouse embryo. $A-C$, Bright-field $(A)$ and dark-field $(B, C)$ photomicrographs of a midsagittal section through an E17.5 mouse embryo. Adjacent sections were hybridized with antisense $(B)$ and sense $(C)$ trkC cRNA probes. Labeled are aorta $(a)$, adipose tissue $(a d)$, cerebellum $(c b)$, dorsal root ganglia $(\mathrm{drg})$, foot $(f)$, olfactory epithelium $(o e)$, paw $(p)$, submaxillary gland $(s m g)$, and anterior tier of thalamic nuclei $\left(\right.$ thal $\left._{a}\right)$. Scale bar, $2350 \mu \mathrm{m}$.

pus (data not shown). In the PNS, trkC transcripts were observed in the otic and trigeminal ganglia as described in the E13.5 embryos (data not shown) as well as the spinal nerves exiting between vertebrae and DRGs (Fig. $4 A, B, D$ ). In the DRGs, trkC transcripts exhibited a more discrete localization than was seen at earlier times (compare Figs. $2 H, 4 D$ ). At E15.5, the majority of the $t r k \mathrm{C}$-expressing cells are located in the ganglia's periphery. Outside of the nervous system, several areas were found to express high levels of $t r k \mathrm{C}$ transcripts. In the head, expression was found in the posterior tongue and lingual glands. In the body cavity, hybridization signal was detected in the wall of the aorta and in the diaphragm. The developing kidney and genital ridge also showed high levels of trkC expression (Fig. 4A,B). Figure $4 C$ shows control adjacent sections hybridized with the sense $t r k \mathrm{C}$ riboprobe.

\section{trkC expression during late embryogenesis}

In the late-stage E17.5 embryo, the majority of the nervous system has been generated and trkC expression is present throughout all levels of the neuraxis (Fig. 5A,B). Hybridization signal was detected in the caudatoputamen as well as a fiber pathway located between the caudate and forebrain subventricular zone. In the diencephalon, heterogeneous expression of $t r k \mathrm{C}$ was noted, with high levels of hybridization signal detected specifically in nuclei of the anterior tier of thalamus (Fig. 5A,B). Relatively high levels of expression were also noted in the medial septal nucleus and the hypothalamus (data not shown). In the mes- and metencephalon, $t r k \mathrm{C}$ expression was located in the tectum and cerebellum, whereas in the hindbrain, labeling was observed in the medulla and spinal cord (Fig. $5 B$ ). Specificity of the signal was shown using a corresponding sense cRNA probe (Fig. $5 C$ ). In the PNS, the majority of the trkC hybridization signal was detected in a subset of neurons located at the periphery of each individual DRG (Fig. 6A,D). This pattern differs from that observed at E11.5, when regardless of position in the ganglia, all of the neurons express $t r k \mathrm{C}$.

In body regions outside of the CNS and PNS, we observed intense trkC hybridization in facial structures such as the vibrissae of the snout, which provide tactile sensory information via the maxillary branch of the trigeminal nerve (Hebel and Stromberg, 1986) (Fig. 5A,B). In this region, the expression of trk C colocalized with neurofibers, as determined by immunostaining of adjacent sections with a monoclonal antibody directed against NFH (data not shown). A similar observation was noted within the tongue and olfactory epithelium (Fig. $5 A, B$ and data not shown). In addition, we identified $\operatorname{trkC}$ transcripts in multilocular adipose tissue (Fig. $5 A, B$ ), cartilagenous regions of the paw (Fig. 5A,B), acini of the submandibular and sublingual glands (Fig. $6 B, E$ ), and in the aortic wall (Fig. $6 C, F$ ).

\section{trkC transcripts in the ENS}

At E17.5, high levels of $t r k \mathrm{C}$ expression were detected in the mesentary of the small intestine as well as in the external muscle layers of the intestinal wall (Fig. $7 A, B$ ). The $t r k \mathrm{C}$ hybridization signal observed in the mesentary is most likely derived from fibers originating in the superior mesenteric, inferior mesenteric, and coeliac ganglia of the PNS. In contrast, the expression of trkC in the submucosal and myenteric plexuses located within the muscular layers of the gut wall is found in regions corresponding to the ENS (Gershon, 1981). To confirm that trkC expression did correlate with nerve fibers, we immunostained adjacent sections with the anti-NFH monoclonal antibody. As shown in Figure $7 C$, the $\operatorname{trkC}$ transcripts appear to be located in the same regions of the splanchnic viscera as NFH immu- 
nostaining. These observations indicate that $t r k \mathrm{C}$ is expressed in the three identified branches of the mammalian nervous system, the CNS, PNS, and ENS.

\section{trkC expression in adult mouse brain}

Northern blot analysis of adult mouse tissues revealed $t r k \mathrm{C}$ abundant transcripts in the brain (Lamballe et al., 1991). To determine the specific distribution of these transcripts in the $\mathrm{CNS}$, we performed in situ hybridization on frozen coronal sections of adult mouse brain. As shown in Figure $8 A$, trkC is expressed in regions of the forebrain, including the cerebral cortex, hippocampus, thalamus, and hypothalamus. Higher magnifications of these regions are depicted in Figure $9 A-D$. In the cerebral cortex, which has a six-layer histotypic organization (Boulder Committee, 1970), trkC shows intense expression in cortical layers 2,3 , and 6 (Fig. 9A). In the hippocampus, the pyramidal cells of Ammon's horn in $\mathrm{CA} 1, \mathrm{CA} 2, \mathrm{CA} 3$, and the hilus exhibit very strong trkC hybridization. Similarly high levels of $t r k \mathrm{C}$ expression were detected in the granule cells of the dentate gyrus (Fig. 9B). In the diencephalon, a strong hybridization is observed in the centromedian region of the thalamus and in the more superficial habenular nuclei (Fig. 9C). The mediodorsal thalamic nuclei that expressed trk $\mathrm{C}$ during embryogenesis do not show any trkC expression in the adult (Fig. $9 C$ ). In the hypothalamus, strong trkC expression can be detected in the dorso- and ventromedial nuclei located adjacent to the third ventricle, as well as in the medium eminence (Fig. $9 D$ ). These results show that $t r k \mathrm{C}$ expression is maintained in adult brain and is specific for certain populations of neurons.

\section{Discussion}

The development of the nervous system requires the coordinated expression of many complex factors. Perhaps foremost of these include the interaction of diffusible factors such as the NGF family of neurotrophins with their cognate signaling receptors. A detailed analysis of the temporal as well as spatial expression of these molecules should provide a better understanding of the basic mechanisms that underlie the organization of the nervous system. In this report, we have investigated the expression of $t r k C$, a gene encoding the receptor responsible for mediating the trophic properties of NT-3 (Lamballe et al., 1991).

In the developing mouse embryo, trkC expression can first be observed in the forebrain and spinal cord at E9.5. From E10 through birth, there is a dynamic pattern of expression that involves both the CNS and PNS. Moreover, the presence of trkC transcripts appears to correlate temporally with axon outgrowth and organogenesis. For example, between E11.5 and $\mathrm{E} 13.5$, trkC transcripts are observed in three areas of the CNS, the auditory system, the cerebellum, and the tectum. In the developing auditory system, $t r k \mathrm{C}$ expression correlates with the appearance of otic ganglion cell fibers leaving the auditory ganglion to begin their migration toward the otic vesicle (Carney and Silver, 1983). A similar correlation is observed in the intermediate zonc of the ccrcbcllum where axons from the nuclcar and Purkinje cells first project toward the cerebellar surface (Yamamoto et al., 1986). In the tectum, which includes the superior and inferior colliculi, two gradients of spatial development occur simultaneously. On one hand, initiation of axon outgrowth proceeds in the cortical plate in an outside-in direction, whereas the tectum develops in a rostral-to-caudal direc- lion. As a result of these developmental gradients, the superior colliculus matures several days before the inferior colliculus (Yamamoto et al., 1986). This pattern of tectal development and axon outgrowth also mirrors $t r k \mathrm{C}$ expression. In fact, by E15.5, when the inferior colliculus has begun axonogenesis (Pickford et al., 1989), trkC transcripts can be homogeneously found throughout the whole of the tectum.

In later embryos (E1 5.5-E17.5), two additional sites within the CNS, the pyramidal cells of Ammon's horn and the germinal trigone of the cerebellum, begin to display trkC transcripts. As observed in the younger embryos, expression of $t r k \mathrm{C}$ correlates both spatially and temporally with cytogenetic gradients of cell growth. In the hippocampus, $t r k \mathrm{C}$ is expressed as the pyramidal cells are born and differentiate from the CA1 through the CA3 regions (Bayer and Altman, 1987). In the cerebellum, a second region of proliferation and differentiation forms several days following the generation of Purkinje and nuclear cells from the ventral neuroepithelium of the fourth ventricle (E11.5; see above). This zone, known as the germinal trigone of the cerebellum, is the initial site of granule cell generation (Smeyne, 1989). trkC expression appears to be turned on when the granule cell precursors begin their initial movement from this laterally situated neuroepithelial region over the surface of the cerebellar cortex to form the external granular layer. To date, the mechanism by which these cerebellar cells translocate over the surface of the cerebellum remains unknown. It has been speculated that this migration occurs through cell-cell interactions mediated by fibronectin (Hatten et al., 1982). Alternatively, it is possible that such migration is mediated by a gradient of neurotrophic factors. The expression of $t r k \mathrm{C}$ transcripts in these cells, along with the previously reported presence of NT-3 in the cerebellum at this stage (Maisonpierre et al., 1990a), lends supports to this hypothesis.

In the PNS, the pattern of $t r k \mathrm{C}$ expression also mimics the timing of axon outgrowth. At E11.5, trkC RNA is already detectable in the DRGs, where axons begin to project to target organs (Rugh, 1990). Interestingly, the pattern of trkC expression in the DRGs undergoes dynamic changes through development. At E1 1.5, DRGs exhibit a trkC hybridization signal homogeneously distributed in all of the large DRG neurons. By E15.5 there is a decline in the total number of DRG neurons expressing $t r k \mathrm{C}$, and by $\mathrm{E} 17.5 t r k \mathrm{C}$-expressing cells are distributed solely in the periphery of the ganglia. It is possible that trkC expression is shut off in certain DRG neurons as part of a defined developmental program. Alternatively, those $t r k \mathrm{C}$ positive neurons located in the central part of the DRGs may die, perhaps as a result of decreasing NT-3 concentrations (Schecterson and Bothwell, 1992). Finally, it is possible that the trkC-positive ganglion neurons are redistributed to the periphery as part of a developmental reorganization of the DRGs. To date, however, there have been no reports of this type of morphogenetic reorganization within the DRGs.

While the appearance of $t r k \mathrm{C}$ transcripts correlates with the initiation of axon outgrowth, its expression is clearly maintained throughout adulthood when no CNS axon growth is observed. This suggests that $t r k \mathrm{C}$, and thus its ligand NT-3, may subserve diverse functions at different times in development. One possibility is that during the initial stages of neuronal development, the signal transduction initiated through the interaction of NT-3 and the $\mathrm{TrkC}$ receptor may play a role in cellular differentiation and survival while later in development, this complex may be used for cellular maintenance. 

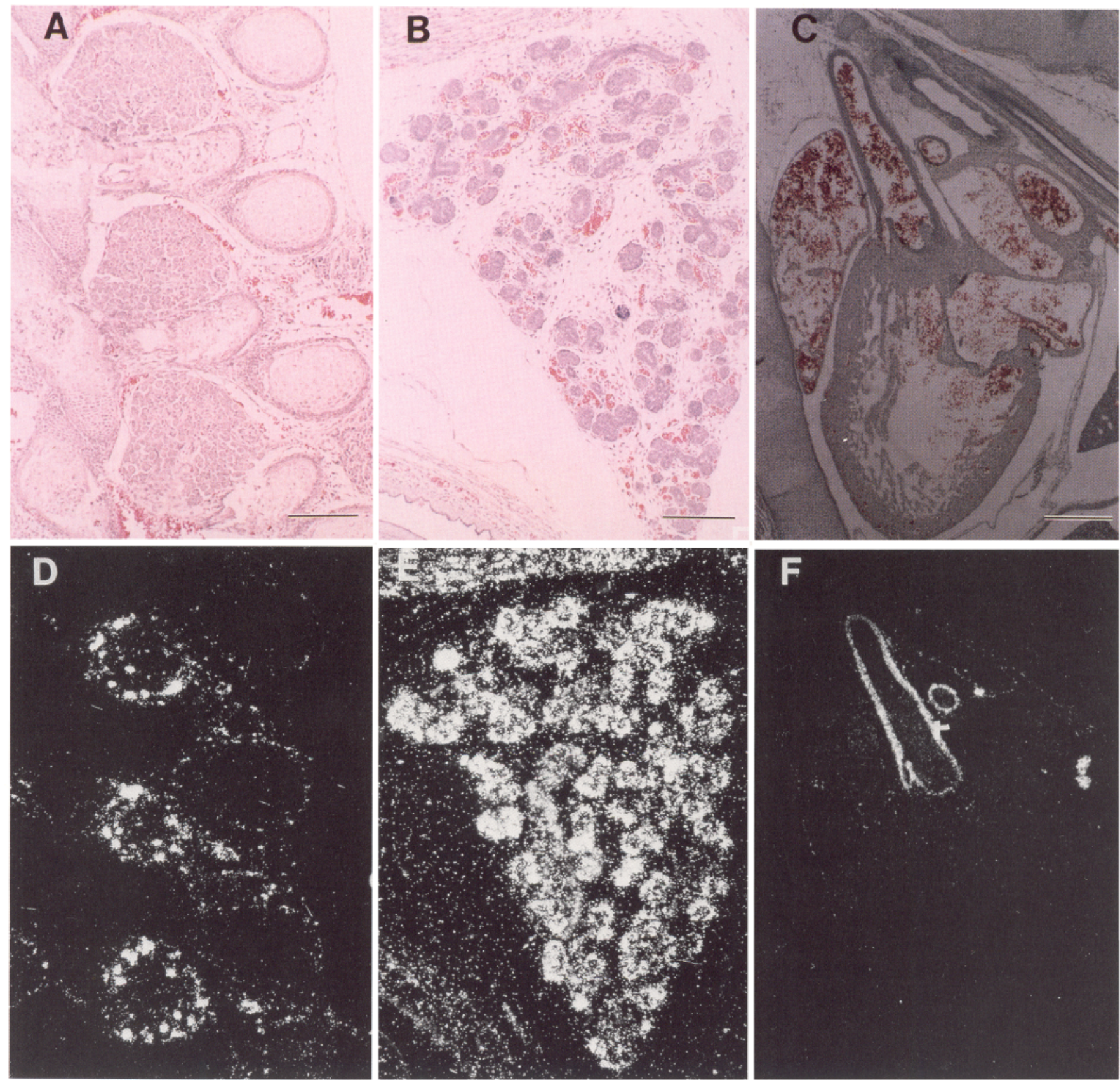

Figure 6. High-power photomicrographs of non-CNS regions of an E17.5 mouse embryo. $A-C$, Toluidine blue-stained bright-field photographs showing DRGs $(A)$, submaxillary gland $(B)$, and heart and aorta $(C) . D-F$, Adjacent sections to $A-C$, respectively, hybridized for $t r k C$ expression. Note the distribution of $t r k C$ transcripts in the periphery of the DRGs and vertebrae $(D)$, submaxillary acini $(E)$, and aorta $(F)$. Scale bars: $A$ and $D, 400 \mu \mathrm{m} ; B, C, E$, and $F, 175 \mu \mathrm{m}$.

The overall pattern of trkC expression in the developing CNS corresponds rather well with that of its cognate ligand, NT-3. Whereas the timing for the onset of NT-3 expression has not been determined, E11 and E12 embryos display a dramatic increase in NT-3 transcripts. Detailed examination of NT-3 expression in three CNS structures, including spinal cord, hippocampus, and cerebellum, revealed a striking correlation between high levels of expression of this neurotrophin with active neurogenesis and the initial formation of axons (Maisonpierre et al., 1990a). For instance, whereas the highest levels of NT-3 transcripts appear at E12 and E13 in the spinal cord, they can be observed between E17 and postnatal day 0 in the hippocampus and during the first 3 weeks after birth in the cerebellum. As described in this report, expression of trkC coincides, both temporally and spatially, with these periods of high NT-3 expression.

Unlike trkC, NT-3 expression declines after these periods to reach low levels in the adult (Maisonpierre et al., 1990a). The reasons for this differential regulation are not well understood. It is possible that once neurogenesis has occurred, the amount of NT-3 required for homeostasis is not as high as for the proliferative and/or growth stages. Regardless of the relative levels 

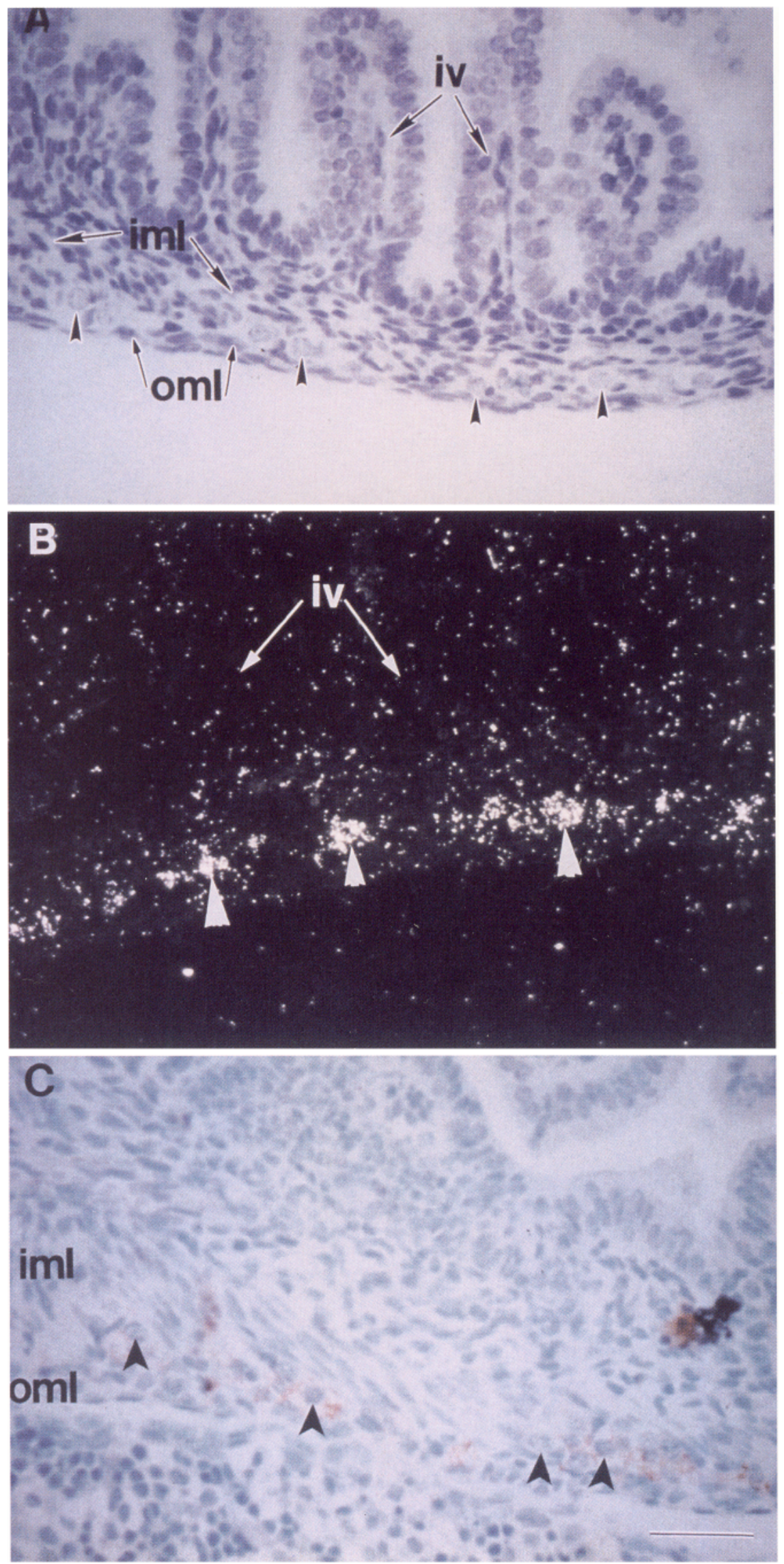

Figure 7. trkC expression in the ENS of an E17.5 animal. $A$, Bright-field photomicrograph of a coronal section through the small intestine showing intestinal villi (iv) and outer (oml) and inner ( $\mathrm{iml}$ ) muscle layers. Arrowheads indicate a minor population of the individual ganglion cells that comprise the myenteric plexus of the ENS. $B$, Darkfield photomicrograph of small intestine in a section representative of that shown in $A$. trkC hybridization is seen in the intestinal muscle layers. No expression is seen within the intestinal villi. $C$, Immunocytostaining with a monoclonal antibody against NF-H. Axons, visualized using an orange chromagen, are observed surrounding the ganglion cells located within the myenteric plexus. The large orange and blue area seen at the right of this picture is debris. Scale bar, $80 \mu \mathrm{m}$. 


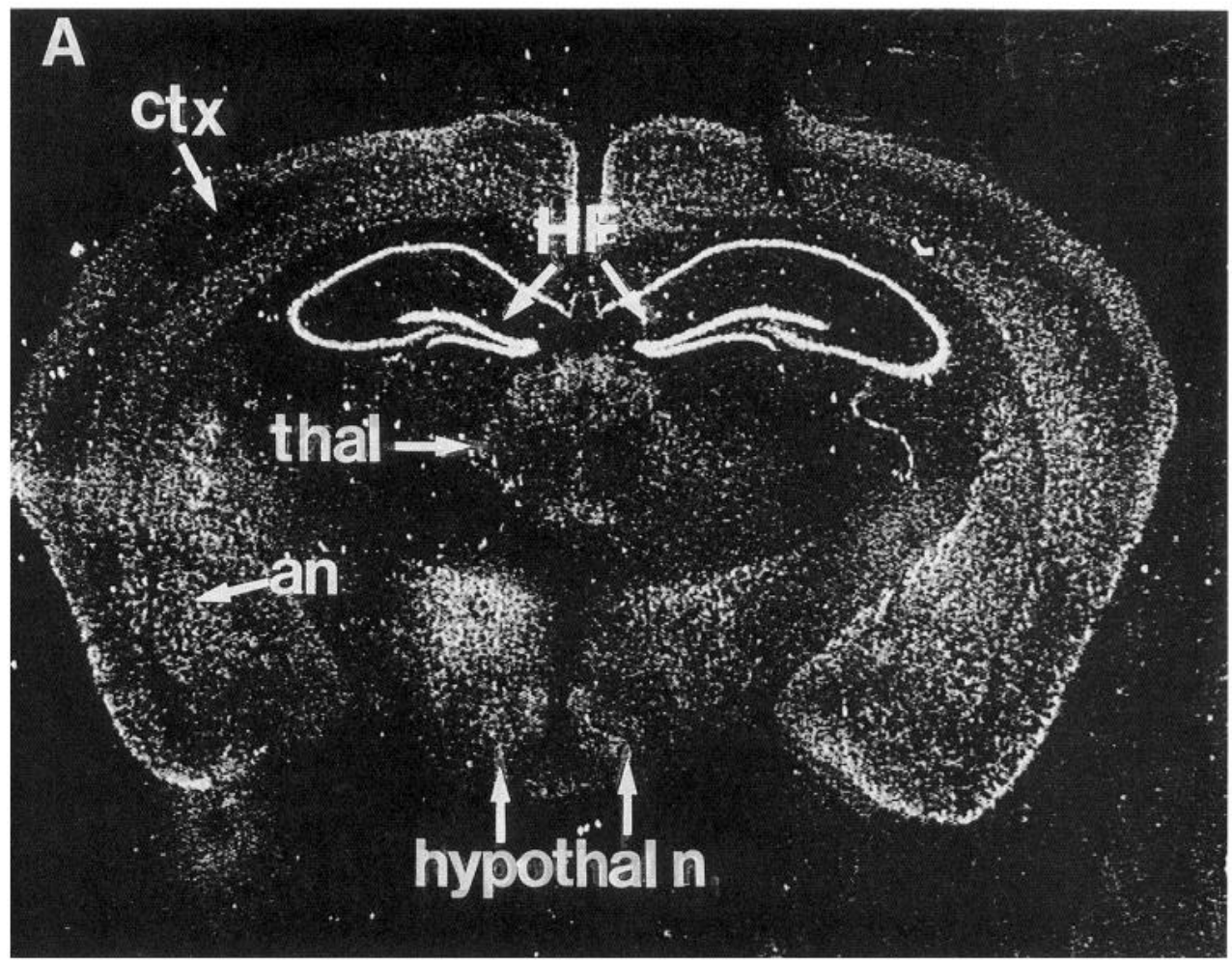

\section{B}

Figure 8. $\operatorname{trk} \mathrm{C}$ expression in the adult mouse brain. $A$ and $B$, Dark-field photomicrograph of adjacent coronal sections of adult mouse brain taken at the level of the dorsal hippocampus and hybridized with either antisense $(A)$ or sense $(B)$ trkC cRNA probes. Expression of $t r k \mathrm{C}$ is observed in the cerebral cortex $(c t x)$ and structures of the limbic system including the hippocampus $(H F)$, amygdaloid nucleus (an), thalamus (thal), and hypothalamus (hypothal $n$ ). Magnification, $15 \times$.

of expression, there is a striking correlation between those regions expressing $t r k \mathrm{C}$ and NT-3 transcripts. In the adult brain, the highest levels of NT-3 expression were detected in the cerebellum and hippocampus (Maisonpierre et al., 1990a). In the hippocampus, expression of NT-3 is predominantly found in the vast majority of dentate granule cells as well as in subpopulations of pyramidal neurons located in CA1 and CA2 (Ernfors et al., 1990b). Low levels of NT-3 mRNA have also been detected in CA3 and CA4 (Winslow et al., 1992). trkC expression is observed throughout the entire pyramidal cell layer as well as in the dentate gyrus. Likewise, trkC is abundantly expressed in the granular layer of the cerebellum, the other adult structure known to maintain significant levels of NT-3 expression. These observations raise the possibility that hippocampal neurons and 

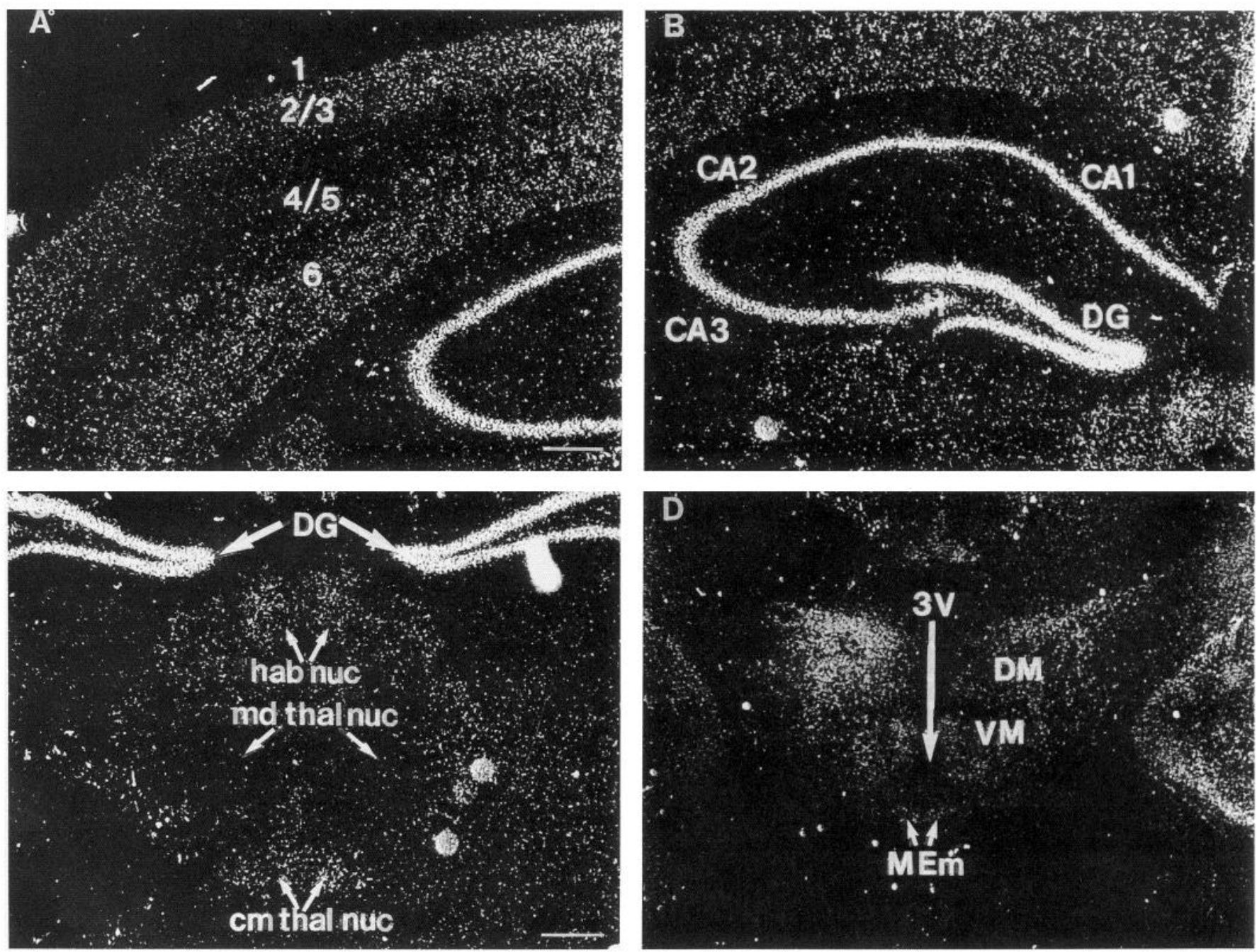

Figure 9. Heterogeneity of $t r k \mathrm{C}$ expression in the adult brain. $A$, In the cerebral cortex, $\operatorname{trk} \mathrm{C}$ hybridization signal is detected primarily in layers 2,3 , and 6. B, In the hippocampus, all regions of Ammon's horn, including CA1, CA2, CA3, and the hilus $(H)$ express trkC. The granule cells located in the dentate gyrus $(D G)$ also express $t r k C$. $C$, In the diencephalon, several thalamic nuclei express $t r k \mathrm{C}$, including the mediodorsal nucleus $(\mathrm{md}$ thal $\mathrm{nuc})$ and the centromedian nucleus $(\mathrm{cm}$ thal nuc). Expression of $t r k \mathrm{C}$ is also detected in the habenular nucleus $($ hab nuc). $D$, In the region of the hypothalamus, high levels of $t r k \mathrm{C}$ expression are noted in both the dorsomedial $(D M)$ and ventromedial $(V M)$ nuclei. In addition, $t r k \mathrm{C}$ transcripts are also seen in the median eminence $(M E n)$. No expression of $t r k \mathrm{C}$ was detected in the ependymal cells lining the third ventricle ( $3 \mathrm{~V}$ ). Scale bar, $275 \mu \mathrm{m}$.

granular cerebellar neurons may be maintained by a mechanism involving autocrine stimulation of $\mathrm{gp} 145^{\mathrm{rk \textrm {C }}}$ receptors.

The pattern of NT-3 mRNA expression has been described in various regions of the PNS as well as in skin, hair follicles (innervated via the trigeminal and DRG), muscle (innervated through the spinal cord motor neurons), and aorta (innervated through the superior cervical ganglia and nodose ganglia) (Schecterson and Bothwell, 1992; Scarisbrick et al., 1993). Comparison of this pattern of expression with that of trkC indicates a significant parallelism between $t r k C$ and NT-3 expression in the embryo. We do not know, however, if within each structure, trkC and NT-3 are colocalized in identical regions, since there are no published developmental in situ studies for this neurotrophin.

The developmental expression of the other known members of the trk gene family has been previously reported (Klein et al., 1990b; Martin-Zanca et al., 1990; Schecterson and Bothwell, 1992). The trk proto-oncogene codes for the signaling NGF receptor (Hempstead et al., 1991; Kaplan et al., 1991; Klein et al., 1991a), while the $t r k \mathrm{~B}$ gene encodes the functional receptor for BDNF (Klein et al., 1991b; Soppet et al., 1991; Squinto et al., 1991) and NT-4 (Berkemeier et al., 1991; Ip et al., 1992; Klein et al., 1992). trk gene expression is restricted to sensory cranial and peripheral ganglia (Martin-Zanca et al., 1990; Schecterson and Bothwell, 1992). In contrast, $t r k \mathrm{~B}$ is widely expressed in the PNS and CNS (Klein et al., 1989, 1990a,b). Comparison of $t r k$ and $t r k C$ expression revealed limited areas of overlap, such as the DRGs and the trigeminal ganglia (Table 1). Whether there is $t r k$ and $t r k \mathrm{C}$ coexpression in some of the other cranial sensory ganglia known to contain trk mRNA remains to be determined.

The expression of $t r k \mathrm{~B}$ and $t r k \mathrm{C}$ exhibits significant areas of overlap, although their spatial and temporal distributions differ (Tables 1,2). For example, these genes are both expressed in the cerebral cortex and in the pyramidal cells of the hippocampus. However, the expression of $t r k \mathrm{C}$ in the dentate gyrus is significantly more pronounced than that of trkB. In addition to these similarities, there are a number of structural subregions 


\begin{tabular}{|c|c|c|c|}
\hline Structure & $t r k \mathrm{C}$ & $t r k$ & $\operatorname{trk\mathrm {B}}$ \\
\hline \multicolumn{4}{|l|}{$\mathrm{CNS}^{\prime \prime}$} \\
\hline Cerebral cortex & $++t^{\prime \prime}$ & - & +++ \\
\hline Corpus callosum & ND & - & - \\
\hline \multicolumn{4}{|l|}{ Hippocampus } \\
\hline Ammon's horn & +++ & - & +++ \\
\hline Dentate gyrus & +++ & - & + \\
\hline Fimbria & ND & - & - \\
\hline Habenular nuclei & +++ & - & +++ \\
\hline \multicolumn{4}{|l|}{ Thalamus } \\
\hline Mediodorsal & +++ & - & ND \\
\hline Centromedian & +++ & - & ND \\
\hline Parafascicular nuclei & ND & - & - \\
\hline \multicolumn{4}{|l|}{ Hypothalamus } \\
\hline Dorsomedial & +++ & - & ND \\
\hline Ventromedial & $++t$ & - & ND \\
\hline Median eminence & +++ & - & +++ \\
\hline Striatum & ND & 111 & ND \\
\hline \multicolumn{4}{|l|}{ Cerebellum } \\
\hline Purkinje cells & - & - & +++ \\
\hline Granule cells & +++ & - & - \\
\hline Spinal cord & $++t$ & - & +++ \\
\hline \multicolumn{4}{|l|}{ Ventricular system } \\
\hline Choroid plexus & - & - & +++ \\
\hline Ependyma & - & - & +++ \\
\hline \multicolumn{4}{|l|}{ PNS } \\
\hline \multicolumn{4}{|l|}{ Cranial ganglia } \\
\hline Trigeminal & +++ & +++ & + \\
\hline Facial & ND & - & +++ \\
\hline Acoustic/otic & +++ & - & $++t$ \\
\hline Superior/jugular & ND & +++ & +++ \\
\hline Petrosal/nodose & ND & - & +++ \\
\hline Dorsal root ganglia & +++ & +++ & + \\
\hline Autonomic system & ++ & - & +++ \\
\hline \multicolumn{4}{|l|}{ ENS } \\
\hline Enteric ganglia & +++ & - & - \\
\hline
\end{tabular}

Expression of $t r k$ and $t r k \mathrm{~B}$ has been previously reported (Klein et al., 1989, 1990a,b; Martin-Zanca et al., 1990).

"Tissue distribution determined in adult animals.

"High $(+++)$, medium $(++)$, or low $(+)$ levels of expression. - , no detectable expression. ND, not determined.

Tissue distribution determined in late stage embryos.

in which these neurotrophin receptors are differentially expressed. For instance, in the cerebellum, high levels of trkB expression are localized in Purkinje cells whereas trkC transcripts are detected in cells of the underlying granule cell layer. Other examples where $t r k \mathrm{~B}$, but not $t r k \mathrm{C}$, are expressed include the internal granular layer (layer 4 ) of the cerebral cortex, the choroid plexus, and the ependymal cell layer of the cerebral ventricles. Moreover, $t r k \mathrm{C}$ appears to be the only member of the trk gene family to be expressed in the autonomous ENS (Table 1). Finally, trkC is abundantly expressed in certain structures outside the nervous system such as the mesenchymally derived cells of arterial walls, acini of the submaxillary and sublingual glands, and dorsal sweat glands (Table 2). To date, neither trk nor trkB has been found to be expressed in nonnervous tissue.
Table 2. trkC expression in tissues outside the nervous system: comparison with $t r k$ and $t r k B$

\begin{tabular}{llll} 
Structure & $t r k \mathrm{C}$ & $t r k$ & $t r k \mathrm{~B}$ \\
\hline Craniofacial structures & & & \\
Retina & & & +++ \\
Vestibular system & $\mathrm{ND}$ & - & + \\
Olfactory epithelium & +++ & - & + \\
Snout & +++ & - & + \\
Submaxillary gland & +++ & - & + \\
Sublingual gland & ++ & - & $\mathrm{ND}$ \\
Tongue & +++ & - & + \\
Other body structures & & & \\
Dorsal sweat glands & +++ & - & - \\
Aorta & +++ & - & - \\
Paws & +++ & - & + \\
Diaphragm & ++ & - & - \\
Hair follicles & +++ & - & ++
\end{tabular}

Expression of $t r k$ and $t r k \mathrm{~B}$ has been previously reported (Klein et al., 1989, 1990a,b; Martin-Zanca et al., 1990).

"Tissue distribution determined in late-stage embryos.

"High $(+++)$, medium $(++)$, or low $(+)$ levels of expression. - , no detectable expression. ND, not determined.

In conclusion, we have shown that trkC, a gene encoding the functional receptor for NT-3, is differentially regulated throughout development. Moreover, its expression correlates well with the process of axon outgrowth and the presence of NT-3 transcripts. These observations suggest that NT-3 and its signaltransducing gp $145^{\text {trc }}$ receptors may generate paracrine and/or autocrine loops responsible, at least in part, for the proliferation and differentiation of neuronal precursors as well as for the growth of newly formed neurons. This possibility can be explored using mice with a targeted mutation of the trkC locus. Recently, we have disrupted the $t r k \mathrm{C}$ gene in embryonic stem cells (unpublished observations) and achieved germ-line transmission of the targeted allele. The in situ expression studies described here, along with the characterization of mice lacking gp 145 rkc receptors, should help unveil the role of $t r k \mathrm{C}$ in the development and maintenance of the mammalian nervous system.

\section{References}

Alderson RF, Alterman AL, Barde YA, Lindsey RM (1990) Brainderived neurotrophic factor increases survival and differentiated functions of rat septal cholinergic neurons in culture. Neuron 5:297-306.

Barbacid M (1993) The Trk family of neurotrophin receptors: molecular characterization and oncogenic activation of human tumors. In: Molecular genetics of nervous system tumors (Levine AJ, Schmidek HH, eds), pp 123-135. New York: Wiley.

Barde YA (1989) Trophic factors and neuronal survival. Neuron 2:1525-1534.

Barde YA, Edger D, Thoenen H (1982) Purification of a new neurotrophic factor from mammalian brain. EMBO J 1:549-553.

Bayer SA, Altman J (1987) Direction in neurogenetic gradients and patterns of anatomical connections in the telencephalon. Prog Neurobiol 29:57-106.

Berkemeier LR, Winslow JW, Kaplan DR, Nikolics K, Goeddel DV, Rosenthal A (1991) Neurotrophin-5: a novel neurotrophic factor that activates $t r k$ and $t r k \mathrm{~B}$. Neuron 7:857-866.

Birren SJ, Verdi JM, Anderson DJ (1992) Membrane depolarization induces p140 rerk and NGF responsiveness but not p $75^{\text {LNGFR }}$, in MAH cells. Science 257:395-397.

Boulder Commmittee (1970) Embryonic vertebrate central nervous system revised terminology. Anat Rec 177:257-261. 
Carney PR, Silver J (1983) Studies on cell migration and axon guidance in the developing distal auditory system of the mouse. J Comp Neurol 215:359-369.

Chao MV (1992) Neurotrophin receptors: a window into neuronal differentiation. Neuron 9:583-593.

Collazo D, Takahashi H, McKay RDG (1992) Cellular targets and trophic functions of neurotrophin-3 in the developing rat hippocampus. Neuron 9:643-656.

Cordon-Cardo C, Tapley P, Jing S, Nanduri V, O'Rourke E, Lamballe F, Kovary K, Klein R, Jones KR, Reichardt LF, Barbacid M (1991) The trk tyrosine protein kinase mediates the mitogenic properties of nerve growth factor and neurotrophin-3. Cell 66:173-183.

Ernfors P, Ibanez CF, Ebendal T, Olson L, Persson H (1990a) Molecular cloning and neurotrophic activities of a protein with structural similarities to nerve growth factor: developmental and topographical expression in the brain. Proc Natl Acad Sci USA 87:5454-5458.

Ernfors P, Wetmore C, Olson L, Persson H (1990b) Identification of cells in rat brain and peripheral tissue expressing mRNA for members of the nerve growth factor family. Neuron 5:511-526.

Gershon M (1981) The enteric nervous system. Annu Rev Neurosci $4: 227-272$

Glass DJ, Nye SH, Hantzopoulos P, Macchi MJ, Squinto SP, Goldfarb M, Yancopoulos GD (1991) TrkB mediates BDNF/NT-3-dependent survival and proliferation of fibroblasts lacking the low affinity NGF receptor. Cell 66:405-413.

Hallbook F, Ibanez CF, Persson H (1991) Evolutionary studies of the nerve-growth factor family reveal a novel member abundantly expressed in Xenopus ovary. Neuron 6:845-858.

Hatten ME, Furie MB, Rifkin DB (1982) Binding of developing mouse cerebellar cells to fibronectin: a possible mechanism for the formation of the external granular layer. J Neurosci 2:1195-1206.

Hebel R, Stromberg MW (1986) Anatomy and embryology of the laboratory rat. Worthsee: BioMed.

Hefti F (1993) Growth factors and neurodegeneration. In: Neurodegenerative diseases, in press. London: Saunders.

Hempstead BL, Martin-Zanca D, Kaplan DR, Parada LF, Chao MW (1991) High-affinity NGF binding requires coexpression of the trk proto-oncogene and the low-affinity NGF receptor. Nature 350:678683.

Hohn A, Leibrock J, Bailey K, Barde YA (1990) Identification and characterization of a novel member of the nerve growth factor/brainderived neurotrophic family. Nature 344:339-341.

Hyman C, Hofer M, Barde YA, Juhasz M, Yancopoulos GD, Squinto SP, Lindsey RM (1991) BDNF is a neurotrophic factor for dopaminergic neurons in the substantia nigra. Nature 350:230-232.

Ibanez CF, Ebendal T, Barbany G, Murray-Rust J, Blundell TL, Persson $\mathrm{H}$ (1992) Disruption of the low affinity receptor-binding site in NGF allows neuronal survival and differentiation by binding to the $t r k$ gene product. Cell 69:329-341.

Ip NY, Ibanez CF, Nye SH, McClain J, Jones PF, Gies DR, Belluscio L, Le Beau MM, Espinosa R III, Squinto SP, Persson H, Yancopoulos GD (1992) Mammalian neurotrophin-4: structure, chromosomal localization, tissue distribution, and receptor specificity. Proc Natl Acad Sci USA 89:3060-3064.

Ip NY, Stitt TN, Tapley P, Klein R, Glass DJ, Fandl J, Greene LA, Barbacid M, Yancopoulos GD (1993) Similarities and differences in the way neurotrophins interact with the Trk receptors in neuronal and non-neuronal cells. Neuron 10:137-149.

Jing S, Tapley P, Barbacid M (1992) Nerve growth factor mediates signal transduction through Trk homodimer receptors. Neuron 9:10671079 .

Johnson D, Lanahan A, Buck CR, Sehgal A, Morgan C, Mercer E, Bothwell M, Chao M (1986) Expression and structure of the human NGF gene. Cell 47:545-554.

Jones KR, Reichardt LF (1990) Molecular cloning of a human gene that is a member of the nerve growth factor family. Proc Natl Acad Sci USA 87:8060-8064.

Kaplan DR, Martin-Zanca D, Parada LF (1991) Tyrosine phosphorylation and tyrosine kinase activity of the trk proto-oncogene product induced by NGF. Naturc 350:158-160.

Klein R, Parada LF, Coulier F, Barbacid M (1989) trkB, a novel tyrosine protein kinase receptor expressed during mouse neural development. EMBO J 8:3701-3709.

Klein R, Conway D, Parada LF, Barbacid M (1990a) The trkB tyrosine protein kinase gene codes for a second neurogenic receptor that lacks the catalytic kinase domain. Cell 61:647-656.

Klein R, Martin-Zanca D, Barbacid M, Parada LF (1990b) Expression of tyrosine kinase receptor gene trkB is confined to the murine embryonic and adult nervous system. Development 109:845-850.

Klein R, Jing S, Nanduri F, O'Rourke F, Barbacid M (1991a) The trk proto-oncogene encodes a receptor for nerve growth factor. Cell 65 : 189-197.

Klein R, Nanduri V, Jing S, Lamballe F, Tapley $\mathbf{P}$, Bryant S, CordonCardo C, Jones KR, Reichardt LF, Barbacid M (1991b) The trkB tyrosine kinase is a receptor for brain-derived neurotrophic factor and neurotrophin-3. Cell 66:395-403.

Klein R, Lamballe F, Bryant S, Barbacid M (1992) The trkB tyrosine protein kinase is a receptor for neurotrophin-4. Neuron 8:947-956.

Knusel B, Winslow JW, Kosenthal A, Burton LE, Seid DP, Nikolics K, Hefti F (1991) Promotion of central cholinergic and dopaminergic neuron differentiation by brain-derived neurotrophic factor but not neurotrophin-3. Proc Natl Acad Sci USA 88:961-965.

Lamballe F, Klein R, Barbacid M (1991) trkC, a new member of the trk family of tyrosine protein kinases, is a receptor for neurotrophin3. Cell 66:967-979.

Lamballe F, Tapley P, Barbacid M (1993) trkC encodes multiple neurotrophin-3 receptors with distinct biological properties and substrate specificities. EMBO J 12:3083-3094.

Leibrock J, Lottspeich F, Hohn A, Hofer M, Hengerer B, Masiakowski P, Thoenen H, Barde YA (1989) Molecular cloning and expression of brain-derived neurotrophic factor. Nature 341:149-152.

Levi-Montalcini R (1987) The nerve growth factor: thirty-five years later. EMBO J 6:1145-1154.

Lindsey RM, Rohrer H (1985) Placodal sensory neurons in culture: nodose ganglion neurons are unresponsive to NGF, lack NGF receptors but are supported by a liver-derived neurotrophic factor. Dev Biol 112:30-48.

Maisonpierre PC, Belluscio L, Friedman B, Alderson RF, Wiegand S.I, Furth ME, Lindsey RM, Yancopoulos GD (1990a) NT-3, BDNF, and NGF in the developing rat nervous system: parallel as well as reciprocal patterns of expression. Neuron 5:501-509.

Maisonpierre PC, Belluscio L, Squinto S, Ip NY, Furth ME, Lindsey RM, Yancopoulos GD (1990b) Neurotrophin-3: a neurotrophic factor related to NGF and BDNF. Science 247:1446-1451.

Martin-Zanca D, Oskam R, Matra G, Copeland T, Barbacid M (1989) Molecular and biochemical characterization of the human trk protooncogene. Mol Cell Biol 9:24-33.

Martin-Zanca D, Barbacid M, Parada LF (1990) Expression of the trk proto-oncogene is restricted to the sensory cranial and spinal ganglia of neural crest origin in mouse development. Genes Dev 4:683-694.

Meakin SO, Shooter EM (1992) The nerve growth factor family of receptors. Trends Neurosci 15:323-331.

Middlemas DS, Lindberg RA, Hunter T (1991) trkB, a neural receptor protein-tyrosine kinase: evidence for a full-length and two truncated receptors. Mol Cell Biol 11:143-153.

Perkins AS, Mercer JA, Jenkins NA, Copeland NG (1991) Patterns of Evi-1 expression in embryonic and adult tissues suggest that $E v i-1$ plays an important regulatory role in mouse development. Development 111:479-487.

Pickford LB, Mayer DN, Bolin LM, Rouse RV (1989) Transiently expressed, neural-specific molecule associated with premigratory granule cells in postnatal mouse cerebellum. J Neurocytol 18:465478.

Rosenthal A, Goeddel DV, Nguyen T, Lewis M, Shih A, Laramee GR, Nikolics K, Winslow JW (1990) Primary structure and biological activity of a novel human neurotrophic factor. Neuron 4:767-773.

Rugh R (1990) The mouse, its reproduction and development. New York: Oxford UP.

Scarisbrick IA, Jones EG, Isackson PJ (1993) Coexpression of mRNAs for NGF, BDNF, and NT-3 in the cardiovascular system of the preand postnatal rat. J Neurosci 13:875-893.

Schecterson LC, Bothwcll M (1992) Novel roles for ncurotrophins arc suggested by BDNF and NT-3 mRNA expression in developing neurons. Neuron 9:449-463.

Smeyne RJ (1989) The development of the weaver cerebellum. PhD thesis, Thomas Jefferson University.

Soppet D, Escandon E, Maragos J, Middlemas DS, Reid SW, Burton LE, Stanton BR, Kaplan DR, Hunter T, Nikolics K, Parada LF (1991) The neurotrophic factors brain-derived neurotrophic factor and 
neurotrophin-3 are ligands for the TrkB tyrosine kinase receptor. Cell 65:895-903.

Squinto SP, Stitt TN, Aldrich TH, Davis S, Bianco SM, Radzicjewski C, Glass DJ, Masiakowski P, Firth ME, Valenzuela DM, DiStefano PS, Yancopoulos GD (1991) trkB encodes a functional receptor for brain-derived neurotrophic factor and neurotrophin-3 but not nerve growth factor. Cell 65:885-893.

Thanos S, Bahr M, Barde YA, Vanselow J (1989) Survival and axon elongation of adult rat retinal ganglion cells. Eur J Neurosci 1:19-26.

Vogels R, De Graaff W, Deschamps J (1990) Expression of the murine homeobox-containing gene Hox-2.3 suggests multiple time-dependent and tissue-specific roles during development. Development 110: $1159-1168$.

Winslow JW, Armanini MP, Laramee GR, Phillips HS, Shih A (1992) Comparison of $t r k \mathrm{C}$ mRNA expression with NT-3 receptor binding autoradiography in brain. Soc Neurosci Abstr 18:227.

Yamamoto M, Boyer AM, Crandall JE, Edwards M, Tanaka H (1986) Distribution of stage-specific neurite-associated proteins in the developing murine nervous system recognized by a monoclonal ant1body. J Neurosci 6:3576-3594. 